\title{
Konseling Rational Emotive Behavior dengan Teknik Pencitraan untuk Meningkatkan Resiliensi Mahasiswa Berstatus Sosial Ekonomi Lemah
}

\author{
Esya Anesty Mashudi \\ Program Studi PG PAUD Universitas Pendidikan Indonesia Kampus Serang \\ Jl. Ciracas Batok Bali, Serang, Banten,Indonesia \\ Email: esyaanesty@upi.edu
}

\begin{abstract}
This research aims to find out the effectiveness of rational emotive behavioral counseling through imagery technique as an effort to enhance the psychological resilience of the students with low socio-economy status. This research used quantitative-qualitative approach with mixed research method. Quasi experimental design to test the effectiveness of the intervention useing non-equivalent pretest-posttest control group design. It was conducted in Universitas Pendidikan Indonesia in Serang Regional Campus by 160 students as participants who were selected using purposive sampling technique. The data was collected by using Adolescence's Resilience Scale and Activity Journal. The result indicated that rational emotive behavioral counseling through imagery technique proved empirically effective to enhance the resilience of the students with low socio-economy status. Based on t-test from pretest and posttest experiment group result, it can be seen that $\mathrm{H}_{0}$ was rejected ( $\mathrm{t}$ count $=8.152$ and $\mathrm{t}$ table $=1.760$.) This research can be used as a reference in improving the resilience of students with low socio-economic status by the guidance and counseling sevice unit in universities, lecturers, counselors at the college to improve low economic status students' resilience.
\end{abstract}

Keyword: lower socio-economy status, imagery technique, resilience, rational emotive behavioral

Penelitian ini bertujuan menguji efektivitas konseling rational emotive behavior dengan teknik pencitraan (imagery) untuk meningkatkan resiliensi mahasiswa dengan latar belakang status sosial-ekonomi lemah Penelitian menggunakan pendekatan kuantitatif kualitatif dengan metode penelitian campuran ( mix methods). Jenis penelitian iniadalah eksperimen kuasi non-equivalentpretest-posttestcontrol group design (pretestposttest dua kelompok). Penelitian dilakukan di Universitas Pendidikan Indonesia dengan subjek penelitian 160 mahasiswa jurusan pendidikan guru pendidik anak usia dini yang diambil melalui teknik purposive sampling. Instrumen penelitian yang digunakan adalah skala resiliensi remaja dan jurnal kegiatan. Hasil penelitian menunjukkan secara empirik, intervensi konseling rational emotive behaviormelalui teknik pencitraan (imagery) teruji efektif untuk meningkatkan resiliensi mahasiswa berstatus sosial-ekonomi lemah khususnya pada aspek efikasi diri. Berdasarkan uji t terhadap hasil pretest dan posttest kelompok eksperimen, diperoleh hasil bahwa $\mathrm{H}_{0}$ ditolak (dengan $\mathrm{t}$ hitung=8,152 dan $\mathrm{t}$ tabel=1,760). Penelitian ini dapat dijadikan rujukan bagi unit pelaksana pelayananan bimbingan dan konseling di perguruan tinggi, dosen,dan konselor di perguruan tinggi untuk meningkatkan resiliensi mahasiswa yang berstatus sosial ekonomi lemah.

Kata kunci: status sosial-ekonomi lemah, teknik pencitraan, resiliensi, rational emotive behavior

\section{Pendahuluan}

Belakangan ini media diramaikan dengan kabar membanggakan mengenai kelulusan putraputri bangsa dari berbagai Perguruan Tinggi di Indonesia. Sejumlah mahasiswa tidak hanya sekedar lulus dan menjadi sarjana, namun lulus dengan predikat Cum Laude dan sederet prestasi lainnya. Beberapa lainnya bahkan mencuri perhatian karena berhasil lulus dengan predikat Cum Laude meskipun berasal dari keluarga dengan latar belakang sosial-ekonomi lemah.

Seperti yang dialami oleh Raeni, putri pasangan Mugiyono dan Sujamah, yang menjadi wisudawan terbaik pada upacara wisuda periode kedua Universitas Negeri Semarang (UNNES).
Meskipun lahir di keluarga kurang mampu dan ayahnya bekerja sebagai tukang becak, Raeni berhasil menunjukkan prestasi yang gemilang di kampusnya. Keberhasilan lain ditunjukkan oleh Abdul Muhammad Rosid, mahasiswa FPMIPA UNY asal Muntilan Jawa Tengah, berhasil meraih IPK sebesar 3,98. Ayah Rosid adalah seorang buruh tani, sementara ibunya bekerja sebagai buruh pembuat gula kelapa (Munir, 2011).

Keberhasilan Raeni maupun Rosid, bukan semata-mata kebetulan atau karena belas kasihan. Keduanya berhasil karena kerja keras dan semangat pantang menyerah yang ditunjukkan selama menimba ilmu di Perguruan Tinggi. Misalnya saja Rosid yang selama berkuliah tinggal di Masjid dan tidak pernah membeli buku, hanya 
meminjam dari perpustakaan atau dari kawannya. Rosid harus cepat-cepat memahami materi karena tidak bisa berlama-lama meminjam buku. Akan tetapi, tidak semua mahasiswa yang berasal dari keluarga dengan status sosial-ekonomi lemah menunjukkan keberhasilan yang cemerlang, banyak pula diantaranya yang memilih mundur sebelum berjuang, ada juga yang berhenti di tengah jalan karena mengalami stress yang kemudian berdampak pada penurunan nilai-nilai akademik, keterlambatan studi dan bahkan drop out.

Beberapa orang mahasiswa penerima beasiswa bidik misi Universitas Brawijaya mengundurkan diri karena menurut mereka kebutuhan untuk bekerja dan menghasilkan uang lebih penting dibanding kuliah. Beberapa mahasiswa lain yang telah aktif berkuliah, terancam drop out setelah dua kali tidak mengikuti UAS tanpa alasan yang jelas (team redaksi UAPKMUB, 2014). Selain itu permasalahan lain yang muncul adalah bunuh diri yang dilakukan mahasiswa. Seorang mahasiswi semester akhir nekad mengakhiri hidupnya dengan cara gantung diri di kamar mandi kos tempatnya tinggal (Armandhani, 2015). Diduga mahasiswi ini mengalami tekanan batin lantaran tidak bisa membiayai SPP semester. Padahal mahasiswi ini sedang dalam proses penyelesaian skripsi. Mahasiswi yang memiliki nilai akademis yang baik ini juga dikenal sebagai mahasiswi yang sederhana dan juga tidak pernah memiliki masalah.

Mengkontraskan fakta-fakta tersebut dengan fakta keberhasilan Raeni dan Rosid, dapat diketahui bahwa ada individu yang mampu bertahan dalam situasi kurang menguntungkan namun ada pula individu yang gagal karena tidak berhasil keluar dari situasi yang kurang menguntungkan. Kemampuan untuk melanjutkan hidup setelah ditimpa kemalangan atau bertahan ditengah lingkungan dengan tekanan yang berat bukanlah sebuah keberuntungan, hal tersebut menunjukkan adanya kemampuan tertentu dalam diri individu yang dikenal dengan istilah resiliensi. Resiliensi berperan untuk ketahanan diri individu dalam menghadapi permasalahan (Tugade \& Frederikson, 2004: 4).

Istilah resiliensi berasal dari kata Latin 'resilire' yang artinya melambung kembali. Awalnya istilah ini digunakan dalam konteks fisik atau ilmu fisika. Resiliensi berarti kemampuan untuk pulih kembali dari suatu keadaan, kembali ke bentuk semula setelah dibengkokkan, ditekan, atau diregangkan. Istilah resiliensi juga banyak digunakan dalam bidang mekanika, aviasi dan komputerisasi. Jika diterjemahkan ke dalam bahasa Indonesia, resiliency berarti gaya pegas, daya kenyal, kegembiraan, keuletan (Echols \& Shadily, 1997; dalam Desmita, 2009: 200), ketahanan (Smet, 1994; dalam Desmita, 2009: 200), daya lentur (Siregar, 2001; dalam Desmita, 2009: 200), daya lambung atau daya lenting (Irawati, 2008: 2). Bila digunakan sebagai istilah dalam bidang psikologi, resiliensi merupakan kemampuan manusia untuk cepat pulih dari perubahan, kesakitan, kemalangan atau kesulitan (The Resiliency Center, 2005; dalam Desmita, 2009: 200).

Asumsi mendasar dalam studi mengenai resiliensi adalah bahwa beberapa individu tetap baik-baik saja meskipun telah mengalami situasi yang sarat adversitas dan beresiko, sementara beberapa individu lainnya gagal beradaptasi dan terperosok dalam adversitas atau resiko yang lebih berat lagi (Schoon, 2006: 9). Reich, J.W, Zautra, A.J, \& Hall, J.(2010: 76) mengemukakan bahwa kemiskinan merupakan salah satu bentuk adversitas yang sangat berpengaruh terhadap kesehatan mental individu terutama era modern. Kondisi ekonomi keluarga yang berada di bawah garis kemiskinan cenderung menjadi stressor bagi anggota keluarga sehingga tidak dapat berfungsi secara optimal dalam kehidupan masyarakat. Sejalan dengan pendapat tersebut, Morland (dalam Barnard, 1999: 40) berdasarkan hasil penelitiannya, mengemukakan bahwa terdapat kecenderungan faktor-faktor resiliensi yang rendah dalam diri anak atau remaja terutama yang berasal dari kelompok sosial-ekonomilemah dan yang telah mengalami dukacita kehilangan orangtua.

Fakta empiris tersebut mengindikasikan pentingnya upaya pembinaan resiliensi dalam diri mahasiswa, khususnya mahasiswa berstatus sosialekonomi lemah karena populasi mahasiswa berstatus ekonomi lemah termasuk ke dalam kategori beresiko (at risk student) yang berpotensi menjadi mahasiswa yang rentan (vulnerable student) dan remaja yang rentan memiliki kecenderungan yang tinggi untuk menjadi mahasiswa bermasalah (troubled student) yang menunjukkan gangguan perilaku maupun kepribadian (Schoon, 2006: 5) 
Beberapa hasil penelitian mendukung bahwa rendahnya tingkat resiliensi dalam diri individu akan menimbulkan kerentanan terhadap resiko dari adversitas. Oleh karena itu, setiap individu perlu diajari keterampilan untuk mampu mengelola dampak negatif dari adversitas menjadi kekuatan dan keterampilan untuk bertahan dalam lingkungan sarat tekanan dan untuk bangkit kembali menuju keberfungsian normal. Upaya peningkatan resiliensi dapat dilakukan melalui pemberian bantuan yang sifatnya terapeutik, salah satunya melalui penggunaan pendekatan konseling yang efektifdalam memfasilitasi pengembangan resiliensi individu. Salah satu pendekatan yang dipandang tepat untuk meningkatkan resiliensi adalah konseling rational emotive behavior.

Alasan pemilihan pendekatan konseling rational emotive behavior untuk meningkatkan resiliensi adalah karena: (1) teori rational emotive behavior merupakan teori yang sudah cukup 'mapan' dan jelas akar sejarah maupun filosofinya (Dryden \& Neenan 2006: 17); (2) berbagai track record konseling rational emotive behavior membuktikan efektivitas dalam menangani perilaku malasuai yang disebabkan oleh pengalaman terhadap adversitas (American Psychiatric Association, 1994; dalam Dryden, 2003: 228); (3) konseling rational emotive behavior memiliki konsep-konsep pokok yang sesuai diaplikasikan dalam upaya peningkatan resiliensi.

Salah satu teknik yang populer untuk digunakan dalam sesi konseling rational emotive behavioradalah teknik pencitraan atau imagery technique. Teknik ini mencakup proses pencitraan suatu situasi tertentu (biasanya situasi yang dipandang kurang menguntungkan bagi konseli) dan mensyaratkan konseli untuk menghadapi situasi tersebut dengan cara mengkonfrontasi keyakinan irrasional menjadi keyakinan yang lebih logis dan rasional sehingga membawa pada munculnya perilaku atau perasaan baru yang lebih tepat pada akhir proses konseling.

Teknik pencitraan merupakan teknik konseling rational emotive behavior yang mudah untuk dilakukan dan dipelajari oleh konseli bahkan diluar sesi pertemuan konseling sekalipun. Teknik ini dapat digunakan untuk melatih konseli memunculkan keyakinan rasional yang dapat menjadi sumber andal untuk mengatasi pengaruh dan konsekuensi negatif dari adversitas di masa lalu, tekanan di masa kini, maupun di masa mendatang yang berada di luar kendali. Dengan demikian diharapkan konseli akan berubah menjadi pribadi yang lebih resilien.

Penelitian ini bertujuan untuk menguji efektivitas konseling rational emotive behavior melalui teknik pencitraan (imagery) untuk meningkatkan resiliensi mahasiswa berstatus sosial-ekonomi lemah. Resiliensi mahasiswa berstatus sosial-ekonomi lemah perlu ditingkatkan agar mahasiswa memiliki kemampuan untuk cepat pulih dari perubahan, kesakitan, kemalangan atau kesulitan yang dialami dalam situasi sosialekonomi lemah. Penelitian ini dapat dijadikan rujukan bagi unit pelaksana pelayananan bimbingan dan konseling di perguruan tinggi, dosen, dan konselor di perguruan tinggi untuk meningkatkan resiliensi mahasiswa yang berstatus sosial ekonomi lemah.

\section{Kajian Literatur}

\section{Resiliensi}

Resiliensi sangat diperlukan bagi individu dalam menghadapi permasalahan dalam kehidupan. Istilah resiliensi berasal dari kata latin 'resilire' yang artinya melambung kembali. Awalnya istilah ini digunakan dalam konteks fisik atau ilmu fisika. Resiliensi berarti kemampuan untuk pulih kembali dari suatu keadaan, kembali ke bentuk semula setelah dibengkokkan, ditekan, atau diregangkan. Bila digunakan sebagai istilah psikologi, resiliensi adalah kemampuan manusia untuk cepat pulih dari perubahan, sakit, kemalangan, atau kesulitan (The Resiliency Center, 2005).

Riedl (Henderson \& Milstein, 2003: 4) mengintrodusir istilah resiliensi psikologis pada tahun 1969, kemudian istilah resiliensi diadopsi sebagai ganti istilah yang sebelumnya telah digunakan para peneliti utuk menggambarkan fenomena seperti invulnerable (kekebalan), invicible (ketangguhan) dan hardy (kekuatan) karena dalam proses menjadi resilien tercakup pengenalan perasaan sakit, perjuangan dan penderitaan. Jika diterjemahkan ke dalam bahasa Indonesia, pengertian resiliency mungkin akan membingungkan seperti gaya pegas, daya kenyal, kegembiraan, keuletan (Echols \& Shadily, 1997), ketahanan (Ismet, 1994) dan daya lentur (Siregar, 2001). Pada tahun 1995, International Resilience 
Project, yang dirintis oleh berbagai lembaga internasional seperti Civilian International Research Centre, UNESCO, Pan American Health Organization, WHO, International Children's Centre, International Chatolic Child Burreau dan Bernard van Leer Foundation, menyepakati definisi dari resiliensi yakni:

"A universal capacity which allows a person, group or community to prevent, minimize or overcome the damaging effect of adversity. Resillience may transform or make stronger the lives of those who are resilient. The resilient behavior may be in responsse to adversity or a pomoter of frowth beyond the present level of functioning. Further, resilience may be promoted not necessarily because of adversity but indeed may be developed in anticipation of inevitable adversities".

Berdasarkan beberapa definisi yang telah dipaparkan maka dapat dipahami bahwa resiliensi adalah kemampuan atau kapasitas insani yang dimiliki seseorang, kelompok atau masyarakat yang memungkinkannya untuk menghadapi, mencegah, meminimalkan dan bahkan menghilangkan dampak-dampak yang merugikan dari kondisi yang tidak menyenangkan atau mengubah kondisi kehidupan yang menyengsarakan menjadi suatu hal yang wajar untuk diatasi (Grotberg dalam Desmita, 2006: 199). Definisi dua dimensi dari resiliensi membawa pada pemahaman mengenai faktor resiko dan faktor protektif. Kedua faktor tersebut memiliki pengaruh penting terhadap tingkat resiliensi individu. Faktor resiko dapat meningkatkan kerentanan individu terhadap adversitas dan menghambat perkembangan resiliensi, sementara faktor protektif dapat memperkuat resiliensi yang membawa pada keberhasilan beradaptasi (Schoon, 2006: 8).

Tinjauan terhadap berbagai literatur tentang resiliensi menghasilkan banyak sifat-sifat atau faktor-faktor resiliensi yang saling overlap. Beberapa faktor protektif internal dari resiliensi terkait dengan aspek-aspek personal dalam individu. Norman (2000: 5) merangkum faktorfaktor yang terkait dengan resiliensi menjadi beberapa area kompetensi internal dan terkait kemampuan coping serta keterampilan hidup yang dapat diukur dan diamati pada diri individu karena individu yang resilien tidak harus memiliki seluruh sifat atau faktor. Faktor-faktor tersebut antara lain efikasi diri, penilaian realistis terhadap lingkungan, keterampilan pemecahan masalah, kemampuan merencanakan dan menentukan tujuan, kemampuan untuk berempati, kemampuan untuk menggunakan humor secara efektif, kemampuan menjaga jarak secara adaptif, peran seksual androgini

\section{Konseling Rational Emotive Behavior sebagai Salah Satu Upaya Peningkatan Resiliensi}

Rational Emotive Behavior Therapy (REBT) atau dalam bahasa Indonesia disebut Terapi Rasional Emotif Perilaku pertama kali digagas oleh Albert Ellis, seorang psikolog klinis asal New York Amerika Serikat, pada tahun 1955. Dalam lingkup Rational Emotive Therapy, manusia pada hakikatnya dipandang sebagai mahluk yang lahir dengan potensi berpikir, baik secara rasional atau lurus maupun irrasional atau bengkok. Dengan anggapan bahwa manusia itu tidak sempurna, RET berusaha menolong seseorang untuk mau menerima dirinya sebagai mahluk yang tidak terlepas dari kesalahan namun pada saat bersamaan juga sebagai mahluk yang bisa belajar dan hidup damai dengan dirinya sendiri.

Model ABC merupakan inti dari praktik konseling REB oleh karena itu implementasinya harus mendapatkan perhatian yang lebih mendetail (Dryden \& Neenan, 2004: 7). A mewakili activating event atau peristiwa pemicu. Terdapat dua jenis A (activating event) dalam konseling REB, yang pertama adalah 'A situasional' yang mengacu pada aspek objektif dari situasi yang mengganggu individu. A kedua adalah 'A kritis' yang mengacu pada aspek subjektif dari situasi yang mengganggu individu. Pada umumnya, 'A kritis' merupakan inferensi dari apa yang terjadi pada 'A situasional'.

B mewakili Beliefs atau keyakinan. Keyakinan merupakan kognisi evaluatif atau pandangan yang terstruktur terhadap hal-hal di sekitar individu, bisa berupa pandangan kaku atau fleksibel, ekstrim maupun non-ekstrim. Ketika keyakinan individu bersifat rigid maka itu dinamakan 'keyakinan irrasional' dan biasanya berupa keharusan, kemutlakan, ataupun kewajiban terhadap sesuatu. Individu yang memiliki keyakinan yang rigid akan cenderung membuat kesimpulan yang irrasional. $\mathrm{C}$ mewakili Consequence, merupakan konsekuensi emosional, pikiran dan perilaku yang muncul dari 
keyakinan atau belief (B) terhadap situasi pemicu atau activating event (A). Dalam konseling REB, $\mathrm{C}$ yang mengikuti keyakinan irrasional tentang A yang negatif akan bersifat mengganggu dan disebut konsekuensi negatif tidak sehat. Sebaliknya, C yang mengikuti keyakinan rasional tentang A yang negatif maka sifatnya tidak mengganggu dan disebut konsekuensi negatif yang sehat (Ellis, 1994; dalam Dryden \& Neenan, 2004).

Konseling REB merupakan pendekatan konseling yang dirancang untuk membantu individu meminimalisir gangguan emosi dan perilaku merusak diri, serta mendorong mereka untuk hidup secara lebih bermakna dan bahagia (Dryden, 2005: 14). Dalam mencapai tujuan tersebut, konselor REB diharapkan membantu konseli untuk : (1) untuk berpikir secara lebih rasional (logis, fleksibel dan ilmiah); (2) untuk merasa lebih sehat; dan (3) untuk bertindak lebih efisien dalam rangka mencapai tujuan dan sasaran mereka (Dryden \& Neenan, 2004: 17).

Teknik pencitraan (imagery technique) dalam Konseling Rational Emotive Behavior

Terdapat beberapa teknik pada konseling REB yang dapat digunakan untuk membantu konseli mengubah sistem keyakinan antara lain teknik kognitif, teknik pencitraan (imagery), teknik emotif-evokatif; dan teknik behavior. Teknik pencitraan dalam konseling rational emotive behavior melibatkan proses dimana konseli menggunakan daya imajinasi untuk menciptakan suatu situasi tertentu dalam pikirannya kemudian selanjutnya konseli diajak untuk menelusuri lebih lanjut alam pikirannya kemudian menggali keyakinan-keyakinan irrasional yang muncul dikarenakan situasi tersebut, setelah keyakinan irrasional berhasil teridentifikasi, konseli dibawa menelusuri berbagai kemungkinan perubahan situasi dan keyakinan rasional yang mengiringi perubahan situasi tersebut (Dryden \& Neenan, 2004: 94). Teknik pencitraan dapat dilakukan menggunakan tiga macam strategi, yakni :

1. Pencitraan rasional emotif, konseli diminta membayangkan gambaran mengenai peristiwa negatif yang menjadi peristiwa pemicu (A) dan mengubah emosi negatif tidak sehat yang mengiringi peristiwa negatif tersebut menjadi emosi negatif yang sehat.
2. Coping imagery, konseli diminta membayangkan suatu situasi dimana ia menggunakan keyakinan irrasional kemudian menggantinya dengan keyakinan rasional.

3. Proyeksi waktu, konseli diminta memilih titik waktu ketika mengalami peristiwa negatif yang dianggap 'sangat buruk' kemudian konseli diajak untuk membayangkan bagaimana kehidupannya pada interval waktu tertentu pasca peristiwa negatif terjadi.

Ketika menggunakan teknik pencitraan ini, konselor dipersyaratkan untuk memiliki kecakapan verbal yang mumpuni, daya kreativitas yang tinggi, serta kemampuan untuk menafsirkan imajinasi konseli. Proses konseling REB melalui teknik pencitraan tetap mengacu pada proses konseling REB pada umumnya yang terdiri atas beberapa tahapan. Dryden dan Neenan (2004: 73) menguraikan tiga tahapan utama dalam konseling REB yakni tahap awal, tahap pertengahan dan tahap akhir. Ketiga tahapan tersebut mencakup 10 sub-tahap.

1. Tahap Awal (Beginning Stage)

a. Membangun aliansi kerja

b. Mengajarkan model ABC pada konseli

2. Tahap Pertengahan (Middle Stage)

a. Mengatasi keraguan-keraguan konseli

b. Mempertimbangkan untuk mengubah fokus masalah

c. Mengidentifikasi dan memodifikasi keyakinan irrasional inti

d. Mendorong konseli untuk terlibat dalam tugas-tugas yang relevan

e. Membantu konseli menginternalisasikan keyakinan rasional baru dengan menggunakan teknik pencitraan (imagery) dalam konseling REB

f. Mengatasi hambatan terhadap perubahan

g. Mendorong konseli untuk memelihara dan meningkatkan apa yang telah dicapai

h. Mendorong konseli untuk menjadi konselor bagi dirinya sendiri

3. Tahap Akhir (Ending Stage)

Dalam tahap akhir ini konselor diperkenankan memberikan penghargaan terhadap konseli atas peran aktif dalam mengikuti sesi intervensi konseling, serta menawarkan layanan konseling individual. 


\section{Metode Penelitian}

Dalam penelitian ini, pendekatan kualitatif dan kuantitatif digunakan secara bersama-sama. Dengan demikian, metode yang dipilih adalah mixed methodology design karena di dalamnya pendekatan kuantitatif dan pendekatan kualitatif dilakukan secara terpadu dan saling mendukung. Desain penelitian eksperimen kuasi yang digunakan adalah nonequivalent pretest-posttest control group design (pretest-postest dua kelompok).

Penelitian dilakukan di Universitas Pendidikan Indonesia Kampus Daerah Serang, dengan mengambil subjek penelitian yakni mahasiswa program studi PGPAUD semester 1-4 sejumlah 160 mahasiswa yang ditentukan secara non-random menggunakan teknik purposive sampling. Instrumen penelitian yang digunakan adalah skala resiliensi remaja dan jurnal kegiatan. Subjek penelitian ditentukan atas dasar kriteria sebagai berikut:

1. Tercatat secara resmi sebagai mahasiswa program studi PGPAUD angkatan 2015, 2014, dan 2013.

2. Tercatat sebagai mahasiswa penerima beasiswa bidikmisi.

3. Penghasilan bruto orangtua per tahun di bawah Rp.12.000.000.-

4. Teridentifikasi memiliki resiliensi dengan tingkatan rendah (kategori kurang resilien) dan sedang (kategori cukup resilien) berdasarkan hasil pengukuran menggunakan instrumen Skala Resiliensi Remaja.

Langkah-langkah penelitian mencakup yakni pretest (pengukuran awal), pemberian perlakuan (treatment) dan posttest (pengukuran akhir). Teknik analisis data kuantitatif yang digunakan antara lain ukuran gejala pusat dan persentase untuk menganalisis data mengenai gambaran tingkat resiliensi mahasiswa berstatus sosialekonomi lemah, uji normalitas terhadap pretest, skor posttest dan gain score kelompok eksperimen dan kontrol sebagai uji prasyarat, serta uji perbedaan dua rerata antara hasil pretest dan posttest yang dianalisis menggunakan $t$-test.

\section{Hasil Dan Pembahasan}

Data hasil penelitian diperoleh melalui penyebaran kuesioner terhadap 160 orang mahasiswa. Kuesioner yang disebar adalah untuk mengidentifikasi mahasiswa yang berasal dari keluarga kurang mampu atau berstatus sosialekonomi lemah. Kemudian dari 160 orang, teridentifikasi 64 orang di antaranya merupakan mahasiswa berstatus sosial-ekonomi lemah, jumlah ini menjadi sampel penelitian. Kemudian instrumen skala resiliensi remaja diadministrasikan terhadap 64 orang mahasiswa tersebut untuk memperoleh data penelitian terkait profil resiliensi mahasiswa berstatus sosialekonomi lemah. Data penelitian menunjukkan profil sebanyak17,42\% dari keseluruhan siswa yang menjadi sampel penelitian memiliki resiliensi pada tingkatan tinggi atau berada pada kategori resilien;67,33\% memiliki resiliensi pada tingkatan sedang atau berada pada kategori cukup resilien; dan $15,24 \%$ memiliki resiliensi pada tingkatan rendah atau berada pada kategori kurang resilien.

Profil resiliensi mahasiswa UPI kampus Serang Banten mayoritas memiliki kecenderungan resiliensi pada tingkat sedang atau termasuk dalam kategori cukup resilien. Hal ini menunjukkan bahwa tingkat kecenderungan resiliensi mahasiswa berstatus sosial-ekonomi lemah belum mencapai tahap optimal dalam arti masih perlu ditingkatkan, ditambah lagi fakta bahwa jumlah mahasiswa yang memiliki kecenderungan resiliensi pada tingkat rendah atau termasuk dalam kategori kurang resilien dapat dikatakan masih cukup banyak. Individu dengan tingkat resiliensi yang rendah dan berada di lingkungan sarat adversitas tidak hanya rentan terhadap gangguan emosional tapi juga terhadap berbagai perilaku maladaptif yang membawa konsekuensi negatif berkepanjangan. Apabila divisualisasikan dalam bentuk grafik, profil resiliensi mahasiswa berstatus sosialekonomi lemah di UPI Kampus Daerah Serang dapat dilihat pada Gambar 1. 


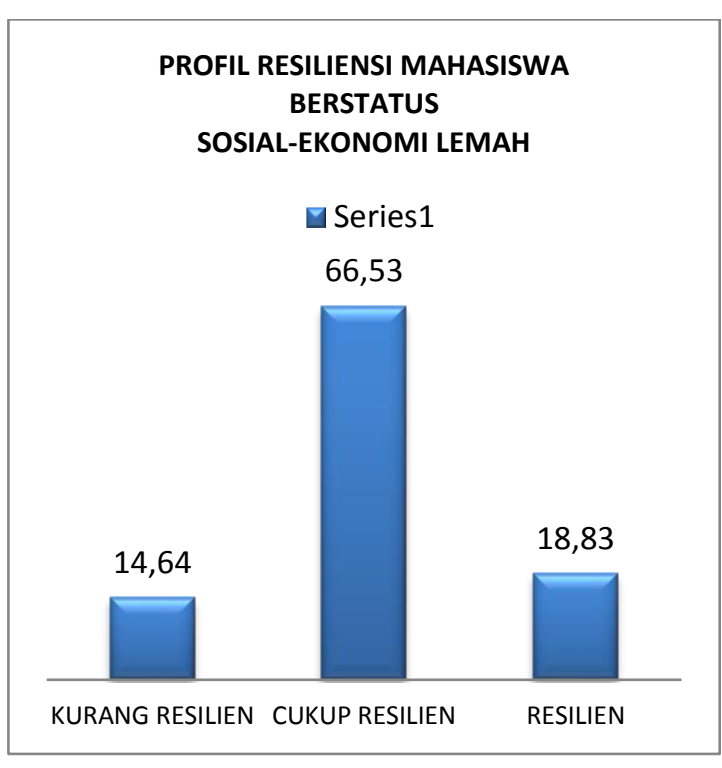

Gambarl

Profil Resiliensi Mahasiswa Berstatus Sosialekonomi Lemah di UPI Kampus Daerah Serang

Thomsen (2002; dalam Castro, Johnson \& Smith, 2011) mengemukakan, "There are seeds of resilience in all of us. Sometimes they get nurtured, and sometimes they do not. Sometimes a person can show incredible strength and resilience in one area of his or her life and not in another." Pernyataan tersebut dijabarkan oleh Castro (2011) sebagai asumsi bahwa semua individu telah memiliki modal yang cukup untuk mengembangkan resiliensi, modal tersebut berupa kapasitas adaptasi yang sifatnya alamiah dan instingtif sehingga individu hanya tinggal membuka lebar kapasitas tersebut untuk meningkatkan kemampuan merespon secara positif dampak negatif dari pengalaman adversitas. Hal tersebut diprediksi menjadi salah satu alasan mengapa dalam banyak studi lainnya tingkatan resiliensi yang dominan ditunjukkan oleh populasi penelitian atau subjek penelitian adalah resiliensi dalam tingkatan sedang, atau rata-rata (average), atau moderat, yakni karena individu memiliki suatu kapasitas alamiah dalam diri mereka untuk merespon terhadap berbagai pengalaman yang sifatnya menyakitkan, menekan, dan mengancam.

Michael Rutter menyatakan bahwa pengalaman adversitas tingkat rendah bisa jadi menguntungkan karena memberikan kesempatan untuk melatih keterampilan pemecahan masalah (problem solving) dan menggerakkan sumber-sumber faktor protektif. Pengalaman terhadap resiko dari adversitas yang cukup menantang namun tidak terlalu kuat dapat menjadi eustress yang baik bagi proses pengembangan diri individu. pengalaman terhadap kondisi dengan tingkat adversitas sedang dapat membuka kesempatan untuk belajar mengenai cara menghadapi adversitas (Rutter, 1985; dalam Schoon, 2006). Oleh karena itu, banyak individu yang secara tidak sadar telah berhasil mengembangkan resiliensi dalam dirinya melalui pengalaman terhadap tantangan yang ditemukan dalam kehidupan sehari-hari. Berbagai eustress mungkin ditemukan dalam kehidupan sehari-hari mahasiswa, khususnya yang berstatus sosial-ekonomi lemah, seperti tugas kuliah yang dianggap sulit, kompetisi akademik, pertengkaran dengan orang terdekat, tekanan dari teman sebaya (dalam intensitas yang masih wajar), serta tantangan saat mengorganisir keuangan dan agenda kegiatan pribadi.

Berbagai kecenderungan yang memperkokoh hasil penelitian terkait tingkatan resiliensi individu yang mayoritas berada pada kategori sedang atau moderat tidak menjadikan upaya untuk meningkatkan resiliensi berkurang urgensinya. Berbagai fakta menegaskan bahwa pengembangan resiliensi sangat diperlukan sebagai kompetensi menghadapi transisi menuju masa dewasa yang sarat tantangan dan tekanan, serta untuk memperoleh status kesehatan mental yang sehat dan terpelihara sepanjang masa kehidupan selanjutnya (Kaplan, 1999; dalam Goldstein \& Brown, 2005: 29).

Dari keseluruhan sampel penelitian yang telah terjaring secara purposif, aspek resiliensi 'penilaian realistis terhadap lingkungan' muncul sebagai aspek yang paling menonjol diantara lainnya, hal ini ditandai dengan nilai rata-rata paling tinggi yakni 78,2; diikuti oleh aspek 'kemampuan merencanakan dan menetapkan tujuan' dengan nilai rata-rata 66,4; 'kemampuan menjaga jarak adaptif' dengan nilai rata-rata 63,5 ; 'kemampuan berempati' dengan nilai rata-rata 61,8; 'efikasi diri' dengan nilai rata-rata 50,3; 'peran seksual androgini' dengan nilai rata-rata 48,9; 'keterampilan pemecahan masalah' dengan nilai rata-rata 36,7 ; dan 'kemampuan menggunakan humor secara efektif' dengan nilai rata-rata $35,4 \%$.

Data penelitian menyiratkan bahwa sebagian besarmahasiswa menunjukkan karakteristik individu resilien berupa kemampuan untuk melakukan penilaian realistis terhadap lingkungan. 
Hasil penelitian ini sejalan dengan studi longitudinal yang dilakukan Werner dan Smith (2001; dalam Goldstein \& Brown, 2005 : 99) terhadap anak-anak di Kepulauan Kauai yang mengungkap bahwa mayoritas remaja laki-laki dan perempuan pada usia 17-18 tahun menunjukkan skor kompetensi skolastik paling tinggi terkait kemampuan membuat penilaian realistis dan efikasi diri. Oleh karena itu, remaja dengan keberfungsian normal dalam hal kognitif, emosional dan behavior menunjukkan kemampuan menentukan sumber-sumber dan membuat perencanaan yang lebih realistis terkait pilihan edukasional dan vokasional mereka pada usia 17 atau 18 tahun.

Werner juga menambahkan, banyak studi menunjukkan bahwa faktor protektif internal utama yang dapat digunakan untuk meningkatkan resiliensi adalah kapasitas untuk membuat penilaian realistis terhadap lingkungan, namun kapasitas ini perlu diperkuat oleh faktor protektif internal lain seperti memiliki pandangan positif terhadap diri sendiri, memiliki kemampuan komunikasi yang baik dan memiliki keterampilan pemecahan masalah (Werner, 1995; dalam Goldstein \& Brown : 99).

Beardslee dan Podorevsky (1998) melakukan penelitian terhadap penderita kanker, pekerja sosial, dan individu dengan orangtua penderita gangguan mental. Penelitian tersebut menemukan bahwa resiliensi berasosiasi dengan kemampuan membedakan antara hal yang mungkin dan tidak, kemampuan menilai konsekuensi dari tindakan secara realistis dan membuat penilaian realistis terhadap kapasitas bertindak dan mempengaruhi suatu situasi. (Cowen, 1990; Garmezzi dan Masten,1996; dan Werner, 1996; dalam Glantz \& Johnson, 2002) mengemukakan bahwa individu yang resilien memiliki persepsi kontrol yang lebih realistis dibanding individu yang tidak resilien.

Selain data yang dianalisis dengan menggunakan persentase dan ukuran gejala pusat, ada juga data yang di analisis menggunakan uji perbedaan dua rata-rata. Analisis tersebut dilakukan untuk menguji hipotesis penelitian yang berbunyi "Konseling rational emotive behaviormelalui teknik pencitraan (imagery) efektif untuk meningkatkan resiliensi diri mahasiswa berstatus sosial-ekonomi lemah." Hipotesis statistiknya adalah sebagai berikut.

$$
\begin{aligned}
& \mathrm{H}_{0}: \mu_{\text {eksperimen }}=\mu_{\text {kontrol }} \\
& \mathrm{H}_{1}: \mu_{\text {eksperimen }}>\mu_{\text {kontrol }}
\end{aligned}
$$

Langkah selanjutnya adalah melakukan analisis statistik untuk mengetahui nilai t hitung (melalui uji $\mathrm{t}$ independen atau uji $\mathrm{t}$ berpasangan) dari skor pretest, skor posttest dan gain score kelompok kontrol maupun eksperimen.

Pengujian efektivitas konseling rational emotive behavior melalui teknik pencitraan (imagery) untuk meningkatkan resiliensi diri mahasiswa berstatus sosial-ekonomi lemah menggunakan teknik uji perbedaan rerata ( $t$-test). Berdasarkan uji $\mathrm{t}$ terhadap hasil pretest dan posttest kelompok eksperimen, diperoleh hasil bahwa $\mathrm{H}_{0}$ ditolak (dengan $\mathrm{t}$ hitung=8,152 dan $\mathrm{t}$ tabel=1,760), dengan demikian hipotesis penelitian yang menyatakan "Konseling rational emotive behavior melalui teknik pencitraan (imagery) efektif untuk meningkatkan resiliensi diri mahasiswa berstatus sosial-ekonomi lemah" secara empiris diterima.

Tujuan uji efektivitas program intervensi adalah untuk memperoleh gambaran mengenai sejauh mana intervensi konseling rational emotive behavior melalui teknik pencitraan (imagery) efektif untuk meningkatkan resiliensi diri mahasiswa berstatus sosial-ekonomi lemah. Hasil analisis terhadap pelaksanaan intervensi konseling tersaji sebagai validitas internal yang membuktikan efektivitas konseling rational emotive behavior melalui teknik pencitraan (imagery) efektif untuk meningkatkan resiliensi diri mahasiswa berstatus sosial-ekonomi lemah, sehingga efektivitas konseling tidak dinilai dengan hanya didasarkan pada angka semata. Hasil uji efektivitas melalui deskripsi dan analisis pelaksanaan intervensi menunjukkan bahwa konseling rational emotive behavior melalui teknik pencitraan (imagery) dapat membantu mahasiswa berstatus sosial-ekonomi lemah untuk meningkatkan resiliensi diri. Hal dibuktikan dengan adanya umpan balik dan kesan-kesan yang positif dari konseli mengenai pelaksanaan konseling. Umpan balik diperoleh melalui instrumen jurnal kegiatan.

Dalam proses konseling, konseli dapat membuat suatu pencitraan dalam pikirannya dan menempatkan diri dalam suatu situasi tertentu. Konselor membantu mengidentifikasi keyakinan irrasional yang muncul seiring situasi tersebut dan 
bagaimana perlawanan terhadap keyakinan irrasional melalui identifikasi keyakinan rasional. Konselor sebagai guru/pengajar dalam hal ini mengotimalkan perannya dengan cara membantu konseli mempelajari keyakinan rasional yang dapat digunakan untuk melawan keyakinan irrasional serta memunculkan respon baru yang lebih adaptif dalam keluar dari situasi citra tertentu, khususnya yang dicitrakan konseli sebagai situasi kurang menguntungkan dan menghambat aktualisasi dirinya.

Penelitian terkait upayapembentukan dan pengembangan resiliensi dalam diri individu maupun sistem sosial masih dalam tahap permulaan meskipun banyak studi klasik mengenai intervensi preventif dapat direkonseptualisasikan untuk memperkaya penelitian seputar resiliensi, meskipun studi-studi tersebut tidak berada dalam kerangka resiliensi pada awalnya. Seperti dikemukakan oleh American Psychologist Association (2006; dalam Hamill, 2009) bahwa perlu lebih banyak upaya diarahkan untuk memahami proses (mediasi, modearsi, promosi dan kompensasi), serta untuk memanipulasi proses tersebut agar lebih efektif dan efisien bagi upaya peningkatan resiliensi individu maupun masyarakat.

Intervensi yang berorientasi pada pendekatan dan teori konseling atau psikoterapi juga memegang peran penting dalam upaya peningkatan resiliensi individu. Beberapa program beorientasi konseling dan psikoterapi yang telah dilaksanakan dan terbukti efektif dalam meningkatkan resiliensi individu yang menjadi subjek intervensi, dirangkum dalam studi metaanalisis yang dilakukan oleh Hooper (2008) yang mengemukakan bahwa terapi kognitif behavior menempati tempat pertama intervensi yang teruji efektif dalam meningkatkan resiliensi individu khususnya mereka yang menjadi korban bencana alam dan pengalaman traumatik lain, sementara logotherapi dari Vicktor Fankl menunjukkan efektivitas terutama pada anak atau remaja yang tinggal di rumah yatim piatu atau panti sosial serta individu yang tinggal di pengungsian atau lembaga pemasayarakatan. Terapi yang terfokus pada solusi (brief solution focused) lebih efektif untuk meningkatkan resiliensi individu dengan pengalaman adversitas kategori sedang seperti yang mengalami kegagalan akademik, drop out, kesulitan membangun relasi sosial dan mengalami separasi dari keluarga.

Studi terbaru terkait efektivitas konseling rational emotive behavior untuk meningkatkan resiliensi dilakukan oleh Mohammad Nasir Bin Bistamam (2009) dari Universitas Pendidikan Sultan Idris (Malaysia). Penelitian menggunakan metode studi kasus terhadap 10 orang remaja korban perceraian orang tua. Dalam studi tersebut diteliti bagaimana efektivitas konseling rational emotive behavior untuk mengembangkan penyesuaian positif (positive adjustment) pada remaja dalam menghadapi perceraian orang tua. Hasil penelitian menunjukkan bahwa pasca intervensi konseling, subjek penelitian mengalami peningkatan tertinggi dalam aspek emosi positif dan resiliensi.

Berbagai keberhasilan yang telah dicapai konseling rational emotive behavior, khususnya terkait upaya peningkatan resiliensi, tidak terlepas dari beberapa kelebihan konseling rational emotive behavior itu sendiri. Konseling rational emotive behavior sangat cocok untuk diaplikasikan dalam sejumlah setting pendidikan untuk menangani berbagai masalah terkait dengan pendidikan, baik dalam situasi kelompok maupun individual. Hal tersebut dikarenakan karakteristik pendekatan rational emotive behavior yang aktif direktif, sehingga sangat menekankan pada peran terapis/konselor sebagai guru/pengajar (Dryden \& Neenan, 2009).

Selain itu, teknik pencitraan dalam konseling rational emotive behavior merupakan teknik yang paling banyak dipilih oleh konseli yang ingin melakukan self-counseling karena dianggap mudah dilakukan dan dapat memberikan penguatan terhadap keyakinan rasional sehingga konseli dapat dengan mudah memunculkan keyakinan rasional tersebut untuk melawan keyakinan irrasional (Neenan \& Dryden, 2004).

\section{Simpulan}

Berdasarkan hasil penelitian maka dapat disimpulkan bahwa konseling rational emotive behaviormelalui teknik pencitraan atau imagerydapatmeningkatkan resiliensi mahasiswa berstatus sosial-ekonomi lemah.Penelitian ini dapat dijadikan rujukan bagi Unit Pelaksana Pelayananan Bimbingan dan Konseling di perguruan tinggi, dosen, dan konselor di perguruan 
tinggi untuk meningkatkan resiliensi mahasiswa yang berstatus sosial ekonomi lemah

\section{Referensi}

Andrews, Bonta \& Wormith. (2004). Resilience and youth criminality. (Online). Tersedia: http: //www.publicsafety.gc.ca (diakses: 24-102010).

Arikunto, S. (2006). Prosedur Penelitian. Jakarta: Rineka Cipta.

Armandhani, Herdian. (2015). Seorang mahasiswi bunuh diri karena tidak mampu membayar uang kuliah. (Online). Tersedia: http: //www.kompasiana.com/blog_archive_herdian _armandhani/093246937 (diakses: 23-072015).

Banaag, C. G. (2002). Resiliency, street Children, and substance abuse prevention .Journal of Prevention Preventif, Nov. 2002, Vol 3.

Barnard, P., Morland, I., \& Nagy, J. (1999). Children, Bereavement and Trauma: Nurturing Resilience. London: Jessica Kingsley Publisher.

Bernard, B. (1995). Fostering Resilience in Children. Journal of the University of Illinois at Urbana Champaign, Children Research Center, Nov. 2002, Vol. 12.

Brannen, J. (1995). Mixing Methods: Qualitative and Quantitative Research. Sydney: Avebury.

Brown, G. W, \& Harris, T. O. (1989). Life events and illness. New York: Guilford.

Castro, Veronica., Johnson, Michael.B., \& Smith, Robert. (2011). Self-Reported Resilient Behaviors of Seventh and Eighth Grade Students Enrolled in an Emotional Intelligence Based Program. (Lecture Paper). Universitas of Texas Pan American.

Chan, D. (1995). Depressive symptoms and coping strategies among Chinese adolescents in Hong Kong. Journal of Youth and Adolescence, 24: 267-279.

Cormier, Sherry., dan Hackney, Harold L. (2009). The Profesional Counselor. Edisi sembilan. New Jerse : Pearson

Cowen, E., Trost, L., Lorion, R., Door, E., Izzo, B. L., \& Isaacson, J. (1975). Evaluation of a preventively oriented, school based mental health program. Journal of Psychology in the Schools, 12(2), 161-166.Creswell, John W. (1994). Research Design Qualitative And
Quantitative Approach, California: SAGE Publications, Inc.

Davis, N.J. (1999). Resilience \& School Violence Prevention: Research-based program. Journal of National Mental Health Information Center, Vol. 8, 28-32.

Daniel, Brigid., \& Wassel, Sally. (2002). Adolescence: Assessing and Promoting Resilience in Vulnerable Children. London: Jessica Kingsley Publisher.

Depdiknas. (2007). Penataan Pendidikan Profesional Konselor dan Layanan Bimbingan dan Konseling dalam Jalur Pendidikan Formal. Jakarta: Depdiknas.

Desmita. (2009). Psikologi Perkembangan. Bandung. Remaja Rosdakarya.

Dumont, M. \& Provost, M. (1999). Resilience in adolescents: Protective role of social support, coping strategies, self-esteem, and social activities on experience of stress and depression. Journal of Youth and Adolescence, 28, 343-363.

Dryden, W. (2003). The REBT pocket companion for clients. New York: Albert Ellis Institute.

Dryden, W., DiGiuseppe, R., \& Neenan, M. (2003). A primer on Rational Emotive Behavior Therapy. Champaign, IL: Research Press.

Dryden, Windy. (2003). Rational Emotive Behavior Therapy, Theoritical Development. New York: Brunner and Routledge Publisher.

Dryden, Windy. (2009). Rational Emotive Behavior Therapy, The CBT Distinctive Feature Series. New York: Routledge.

Ellis, A. (2001b). Overcoming destructive beliefs, feeling and behaviors. Amherst, NY: Prometheus Books.

Ellis, A. (2001c). Rational and irrational aspects of countertransference. Journal of Clinical Psychology, In session: Psychotherapy in Practice, 57, 999-1004.

Ellis, A., \& Becker, I. (1982). A guide to personal happiness. North Hollywood, CA: Melvin Powers Publishing.

Ellis, A., \& Blau. S. (1998). (Eds). The Albert Ellis reader. New York: Kensington Publishers.

Ellis, A., \& Dryden, W. (1997). The practice of rational emotive behavior therapy. New York: Springer.

Furqon. (1997). Statistika Terapan untuk Penelitian. Bandung: Alfabeta. 
Fuller, Andrew. (2002). Raising Real People: Creating a Resilient Family 2nd edition. Melbourne, Australia: Acer Press.

Fraenkel, J.R., \& Wallen, N.E. (1993). How to Design and Evaluate Research in Education. New York: McGraw Hill.

Gall, Meredith D., Gall, Joyce P., \& Borg, Walter R. (2003). Educational Research: an Introduction (Seventh Edition). New York: Pearson Education Inc.

Garbarino, J., Dubrow, N., Kostelny, K., \& Pardo, C. (1992). Children in Danger: Coping with the Consequences of Community Violence. San Francisco: Jossey-Bass Publishers.

Garbarino, J. (2011). The Positive Psychology of Personal Transformation: Leveraging Resilience for Life Change. New York: Springer Science and Business Media, Inc.

Garmezy, N., \& Rutter, M. (1983). Stress, Coping, and Development in Children. New York: McGraw-Hill.

Garmezy, N., Masten, A. S., \& Tellegen, A. (1984). The study of stress and competence in children: A building block for developmental psychopathology. Journal of Child Development, 55,97-111.

Gladding, Samuel T. (1995). Group Work: A Counseling Specialty. Second edition. New Jersey: Merrill an Imprint of Prentice-Hall.

Glantz, Meyer D., \& Johnson, Jeannette. L. (2002). Resilience and Development: Positive Life Adaptations. New York: Kluwer Academic Publisher.

Goldstein, Sam., \& Brooks, Robert. B. (2005). Handbook of Resilience in Children. New York, USA : Springer Science and Business Media, Inc.

Goldstein, S., \& Brooks, R. (2002). Nurturing resilience in our children: Answers to the most important parenting questions. New York: Contemporary Books.

Grotberg, E. (1995). A Guide to Promoting Resilience in Children: Strengthening The Human Spirit. Benard Van Leer Fondation.

Grotberg, E.H. (1997). The International Resilience Project. Papar presented at the International Council of Psychologists conference. 5, 213-244.

Gysbers, N. C., \& Henderson, P. (2010). Developing and managing your school guidance program (2 ${ }^{\text {nd }}$ ed.). Alexandria, VA:
American Association for Counseling and Development.

Gysbers, N. C., \& Moore, E. J. (1994). Improving guidance programs. Englewood Cliffs, New Jersey : Prentice Hall.

Hamill, S.K. (2009). Resilience and Self Eficacy. Journal of Science, Volume 18. Colgate University.

Hasanudin, Aco. (2014). Putri tukang becak menjadi wisudawan terbaik. (Online).Tersedia: http:

//www.tribunnews.com/search_archive(diakses : 03-01-2015).

Hiew, C. C., Mori, T., Shimizu, Masuharu., \& Tominaga, Mihoko. (2000). Measurement of Resilience Development: Preliminary Result with a State Trait Resilience Inventory. Journal of Learning \& Faculty of Education, Volume I. Hirosima University.

Hooper, Lisa. M. (2009). Individual and Family Resilience: Definitions, Research, and Frameworks (Relevant for All Counselors). The Alabama Counseling Association Journal, Volume 35, no 1. 19-26.

Hurlock, E. (a.b. Istiwidayanti \& Soedjarwo). (1992). Psikologi Perkembangan: Edisi Kelima. Jakarta: Erlangga.

Hutchinson, G.T., \& Chapman, B.P. (2005). Logotherapy - Enhanced REBT: An Integration of Discovery and Reason. Journal of Contemporary Psychotherapy, 35(2), 145155.

Kappara, Mardiana. (2011). Broken Home, No Problem. (Online). Tersedia: http: //pusatremaja.com/tag/broken-home/ (diakses : 03-02-2012).

Kelly, J. B.,\& Emery, R. E. (2003). Children's adjustment following divorce: Risk and resilience perspectives. Family Relations: Interdisciplinary Journal of Applied Family Studies, 52, 352-362.

Klohnen, E.C. (1996). Conseptual Analysis and Measurement of The Construct of Ego Resilience. Journal of Personality and Social Psychology, Volume. 70 No 5, p 1067-1079.

Luthar, S. S., Cicchetti, D., \& Becker, B. (2000). The construct of resilience: A critical evaluation and guidelines for future work. Journal ofChild Development, 71, 543-562.

Liquanti, R. (1992). Using Community-wide Collaboration to Foster Resiliency in Kids: A 


\section{MASHUDI}

Conceptual Framework Western Regional Center For Drugs-Free School and Communities, Far West Laboratory fo Educational Research and Development. San Fransisco. (Online). Tersedia: http: //www.ncrel.org/sdrs/cityschool/citu11bhtm (diakses: 24-10-2010).

Masten, A. S., Best, K. M., \& Garmezy, N. (1990). Resilience and development: Contributions from the study of children who overcome adversity. Journal ofDevelopment and Psychopathology, 2, 425-444.

Mohamad, Surya. (2003). Psikologi Pembelajaran dan Pengajaran. Bandung: Yayasan Bhakti Winaya.

Munawaroh, E. (2011). Program Bimbingan Belajar Untuk Meningkatkan Resiliensi Akademik Siswa Boarding School. (Skripsi). Bandung: Universitas Pendidikan Indonesia.

Munir, Rinaldi. (2011). Tinggal di mesjid agar bisa tetap berkuliah. (Online). Tersedia: http: //www.rinaldimunir.wordpress.com/archive/de cember (diakses : 03-01-2015).

Moltz, Barry, J. (2008). Bounce! - Failure, Resiliency and Confidence to Achieve Your Next Great Success. New Jersey: John Wiley \& Sons. Inc.

Nana Syaodih, Sukmadinata. (2005). Metode Penelitian Pendidikan. Bandung: Remaja Rosdakarya.

Natawidjaja, R. (1987). Pendekatan dalam Penyuluhan Kelompok. Jakarta: Depdikbud. Ditjen Dikti. Proyek Pengembangan Lembaga Pendidikan dan Tenaga Kependidikan.

Neenan, Michael \& Dryden, Windy. (2004). The Rational Emotif Behavior Counseling in Action. Londo : Sage Publications.

Neenan, Michael \& Dryden, Windy. (2004). The Rational Emotif Behavior Approach to therapeutic change. London: Sage Publications.

Neenan, Michael \& Dryden, Windy. (2006). Rational Emotif Behavior Therapy in a nutshell. London: Sage Publications.

Neenan, Michael. (2009). Developing Resilience, A Cognitive Behavior Approach. New York: Routledge.

Neil, James. (2006). What is resilience?. (Online). Tersedia : http: //www.about.com (diakses: 12-04-2010).
Norman, Elaine. (2000). Resiliency Enhancement: Putting Strengths Perspective into Social Work Practice. USA : Columbia University Press.

Nurihsan, Juntika. (2003). Dasar-Dasar Bimbingan dan Konseling. Bandung: Mutiara.

Parinyaphol, P., \& Chongruksa, D. (2008). Resilience of Higher Educational Students: The Human Spirit Among Thai and Muslim Students. Journal in Department of Psychology and Guidance, Prince of Songkla University (7: 08).

Peters, Ray. D., Leadbeater, Bonnie., \& McMahon, Robert.J. (2005). Resilience in Children, Families and Communities: Linking Context to Practice and Policy. New York : Kluwer Academic/Plenum Publishers.

Richardson, G. E., Neiger, B. L., Jensen, S., \& Kumpfer, K. (1990). The resihency model. Health Education, 27(6), 33-39.

Richmond, J. B. \& Beardslee, W. R. (1988). (Resiliency: Research and pracital applications for pediatricians. Journal of Developmental and Behavior Pediatrics, 9 (3), June, 157-163.

Reich, J.W, Zautra, A.J, \& Hall, J. (2010). Handbook of Adult Resilience. New York : The Guildford Press.

Reivich, K. \& Shatté, A.(2002). The resilience factor: 7 essential skills for overcoming life's inevitable obstacles. New York: Broadway Books.

Schoon, Ingrid. (2006). Risk and Resilience, Adaptations in Changing Times. New York : Cambridge University Press.

Siebert, Al. (2005). The Resiliency Advantage : Master Change, Thrive Under Pressure, and Bounce Back from Setbacks. Berret-Koehler Publishers, Inc.

Stewart, Ann. (2011). Sense of purpose. Online. Tersedia: http: //EzineArticles.com/?expert=Ann_Stewart/sens e_of_purpose.htm (diakses : 05-01-2012).

Sudjana. (1996). Metode Statistika. Bandung: Penerbit Tarsito.

Supriatna, M. (2010). Model Konseling Aktualisasi Diri untuk Meningkatkan Kecakapan Pribadi Mahasiswa. (Disertasi). Bandung : Universitas Pendidikan Indonesia.

Suwarjo. (2008). Model Konseling Teman Sebaya untuk Mengembangkan Daya Lentur Anak Asuh. (Disertasi). Bandung: Universitas Pendidikan Indonesia. 
Tadjri, Imam. (2008). Model konseling kelompok berbasis pendekatan rasional emotive therapy untuk menanggulangi kenakalan remaja. (Disertasi). Bandung: Universitas Pendidikan Indonesia.

Tim redaksi UAPKMUB. (2014). Mahasiswa Penerima Beasiswa Bidikmisi Mengundurkan Diri. (Online). Tersedia: http: //www.kavling10.com/news/kavmedia_archive (diakses : 23-07-2015).

Tim Redaksi. (2011). Peran keluarga dalam menyelamatkan korban narkoba. (Online). Tersedia: http: //www.kabarcirebon.com(diakses : 03-02-2012).

Tugade, M. M., \& Fredrickson, B. L. (2007). Regulation of positive emotions: Emotion regulation strategies that promote resilience. Journal of Happiness Studies: Special Issue on Emotion Self-Regulation, 8, $311-333$.

Tugade, M. M. \& Fredrickson, B. L. (2004). Resilient individuals use positive emotions to bounce back from negative emotional experiences. Journal of Personality and Social Psychology, 86, 320 - 333.

Vargas-Reighley, Rosalva, V. (2005). Bicultural Competence and Academic Resilience among Immigrants. New York: LFB Scholarly Publishing LLC.

Wahyuningsih, Sri .(2004). Indeks statistik kenakalan remaja. (Online). Tersedia: http: //www.depsos.go.id (diakses: 03-02-2012).

Werner, E. \& Smith, R. (1991) Overcoming the odds: High risk children from birth to adulthood. New York: Cornell University Press.

Yusuf, Syamsu., dan Nurihsan, A. Juntika. (2009). Landasan Bimbingan dan Konseling. Bandung: Rosda Karya. . (2009). Suicidal risk in adolescence. (Online). Tersedia: http: //www.depressiondoctor.com (diakses: 03-02-2012).

(2010). Increasing attendant rate in school : study of children from low social economy status. (Online). http: //www.edjj.com (diakses : 03-02-2012).

(2010). Suicide in US: Statistic and

Prevention. (Online). Tersedia: http: //www.nimh.nih.gov/health/publications/suicid e-in-the-us-statistics-and- prevention/index.shtml/index.shtml (diakses: 03-02-2012).

.(2010). Prostitusi di kalangan remaja.

(Online). Tersedia: http:

//www.spiriteen.wordpress.com (diakses: 0302-2012). 